\title{
PERBANDINGAN LARUTAN FIKSATIF NAFS DENGAN ALKOHOL 96\%-NBF 10\% DALAM PEMBUATAN BLOK SEL PADA SAMPEL CAIRAN PLEURA
}

\author{
Dewi Inderiati ${ }^{1 *}$, Bella Eka Pratiwi ${ }^{1}$ \\ 1 Jurusan Teknologi Laboratorium Medis, Potekkes Kemenkes Jakarta III, Indonesia \\ e-Mmail: dregina.biomedic@gmail.com
}

\begin{abstract}
Pleural fluid is a liquid located in the pleural cavity, between the pleural visceral and pleural parietal. Analysis of pleural fluid is mandatory in all cases of diseases that give rise to pleural effusion. Cytopathological test gives the first indication of malignancy in malignant effusion, one of which is by making cell block. The stages of making cell block begin with fixation to maintain the cell component and its state is close to the original. The purpose of this study was to determine the comparison of the quality of the cytopathological examination results from the manufacture of cell block using a fixative solution of Nathan Alcohol Formalin Substitute (NAFS) and alcohol 96\% -NBF 10\% in pleural fluid samples. Experimental research with cross-sectional research design. The results showed that 13 samples of pleural fluid preparations in cell block preparations with NAFS fixative solution and cell block preparations with $96 \%-N B F 10 \%$ alcohol fixative solution there was no significant difference in the morphological figure of the cells, the number of cells produced, the number of malignant cells analyzed, the absorption of staining and cytodiagnosis sensitivity. Based on the results of this study, it can be concluded that alcohol $96 \%$-NBF $10 \%$ can be used as an alternative solution to fixative for pleural fluid samples.
\end{abstract}

Keywords : alcohol 96\%-NBF 10\%, Pleural fluid, NAFS fixative

\begin{abstract}
Abstrak
Cairan pleura merupakan cairan yang berada di rongga pleura, diantara pleura viseralis dan pleura parietalis. Analisis cairan pleura wajib dilakukan pada semua kasus penyakit yang menimbulkan efusi pleura. Pemeriksaan sitopatologi memberikan indikasi pertama keganasan pada efusi ganas, salah satunya dengan pembuatan blok sel. Tahapan pembuatan bloksel diawali dari fiksasi untuk mempertahankan komponen sel serta keadaannya mendekati seperti aslinya. Tujuan dari penelitian ini adalah untuk mengetahui perbandingan kualitas hasil pemeriksaan sitopatologi dari pembuatan blok sel yang menggunakan larutan fiksatif Nathan Alcohol Formalin Substitute (NAFS) dan alkohol 96\%NBF $10 \%$ pada sampel cairan pleura. Penelitian eksperimental ini menggunakan desain penelitian cross-sectional. Hasil penelitian terhadap 13 sampel cairan pleura dalam pembuatan sediaan blok sel dengan larutan fiksatif NAFS serta sediaan blok sel dan larutan fiksatif alkohol 96\%-NBF 10\% menunjukan tidak terdapat perbedaan bermakna pada gambaran morfologi sel, banyaknya sel yang dihasilkan, banyaknya sel ganas yang teranalisa, penyerapan pewarnaan, dan sensitivitas sitodiagnosis. Berdasarkan hasil dari penelitian ini dapat disimpulkan bahwa alkohol 96\%-NBF 10\% dapat digunakan sebagai larutan alternatif untuk fiksatif pada sampel cairan pleura.
\end{abstract}

Kata Kunci : alkohol 96\%-NBF 10\%, Cairan pleura, Fiksatif NAFS 


\section{PENDAHULUAN}

Cairan pleura merupakan cairan yang berada di rongga pleura, tepatnya diantara pleura viseralis dan pleura parietalis. Dalam keadaan normal jumlah cairan pleura sangat sedikit yaitu 0,1-0,2 mL/kg BB. Efusi pleura adalah akumulasi cairan pleura tidak normal di rongga pleura yang diakibatkan oleh transudasi atau eksudasi yang berlebihan dari permukaan pleura. Cairan pleura dapat terakumulasi saat kecepatan pembentukan cairan pleura melebihi kecepatan absorbsinya (Khairani dkk, 2012).

Beberapa penyakit yang dapat menimbulkan efusi pleura antara lain tuberkulosis, infeksi nontuberkulosis, sirosis hepatis, gagal jantung kongestif, kanker paru, empiema dan keganasan (Prasetyani, 2017; Kristina, 2014; Rahman dkk, 2011). Setengah dari penderita kanker mengalami metastasis ke ruang pleura dan menyebabkan terjadinya efusi. Lebih dari 75\% penderita dengan efusi pleura dicurigai ganas disebabkan oleh metastasis yang berasal dari paru, ovarium atau lymphoma (Hezer dkk, 2015). Pada pasien pria, sekitar setengah dari efusi tersebut disebabkan oleh kanker paru-paru. Pada kanker paru-paru, efusi pleura ganas bisa menjadi tanda pertama kanker, atau sebagai komplikasi lanjut suatu penyakit (Syahruddin dkk, 2010)

Analisis cairan pleura wajib dilakukan pada semua kasus penyakit yang menimbulkan efusi pleura. Analisis cairan pleura meliputi makroskopis, kadar glukosa, jumlah leukosit, hitung jenis leukosit, LDH (Laktat Dehidrogenase), total protein, uji mikrobiologi dan sitologi keganasan (Rahman dkk, 2011). Metode pemeriksaan sitologi dari cairan pleura saat ini merupakan prosedur rutin yang paling spesifik untuk membedakan efusi pleura ganas dan tidak ganas, serta sudah dianggap sebagai metode alternatif untuk membantu menegakkan diagnosis kanker paru (Satolom dkk, 2012). 60\% kasus efusi ganas dapat didiagnosis berdasarkan sitologi cairan pleura (Boka, 2017). Metode ini juga relatif lebih ekonomis dan kurang berisiko dibandingkan dengan pemeriksaan histopatologi hasil biopsi dan diharapkan sensitivitasnya lebih tinggi dari FNAB (Fine Needle 
Aspiration Biopsy) (Kristina, 2014; Ettinger DS, 2011).

Pemeriksaan sitopatologi memberikan indikasi pertama keganasan pada efusi ganas. Ada berbagai metode sitopatologi yang tersedia diantaranya metode pulasan konvensional, metode Cytospin atau Cytocentrifuge, dan metode blok sel (Santoshpawar dkk, 2016). Metode pulasan konvensional efusi merupakan metode yang paling sering dilakukan karena cepat dan hemat biaya. Tetapi, karena detail morfologi sel kurang terlihat, terlalu padat atau sel tumpang tindih, kehilangan sel, sehingga diagnosis sulit dicapai (Mulkalwar, 2016). Pada metode cytospin, sel pada corong akan terkonsentrat di kaca objek. Optimalisasi juga dapat dilakukan pada cairan hiposeluler. Tetapi tidak semua laboratorium memiliki Cytocentrifuge dan cytoclip karena harganya relatif mahal (Hu dkk, 2015).

Metode blok sel merupakan padatan yang dibuat dari spesimen konsentrat dengan prinsip gel atau koagulasi yang kemudian dilanjutkan dengan proses pematangan jaringan dan embedding serta pewarnaan seperti pada histologi (Nathan, 2015; Varsegi \& Shidham, 2009). Selain untuk dilakukan penilaian sel, bloksel juga dapat digunakan untuk pemeriksaan sitologi lanjutan yang lain seperti imunositokimia dan molekular tumor. Spesimen yang dapat dibuat bloksel antara lain cairan efusi, aspirasi jarum halus, sikatan dan isi kista. Kekurangan pada metode bloksel yaitu hasil diagnosis tidak dapat ditegakkan dalam waktu cepat jika dibandingkan dengan pulasan konvensional dikarenakan pengerjaan bloksel lebih lama dari pada pulasan konvensional. Selain itu, kualitas DNA pada pulasan konvensional dan cytospin cenderung lebih baik dibandingkan bloksel karena tidak terdapat degradasi asam nukleat seperti oleh fiksasi formalin (Chowdhuri dkk, 2015). Tetapi metode yang sering dipilih untuk NextGeneration Sequencing pada sitologi adalah bloksel karena lebih mudah untuk diproses serta baik digunakan pada sampel dengan selularitas rendah. Disamping itu, memungkinkan untuk menambah potongan tanpa pewarnaan dari bloksel (Chowdhuri dan Stewart, 2016). Metode blok sel terbukti dapat menghasilkan lebih banyak sel, gambaran morfologi yang lebih baik dan tambahan sel ganas sehingga meningkatkan sensitivitas sitodiagnosis 
dibandingkan dengan pulasan konvensional (Shivakumarswamy dkk, 2012; Shobha \& Kodandaswamy, 2013).

Selain itu, pewarnaan pada blok sel menghasilkan pewarnaan tanpa latar belakang sehingga tidak mengganggu pengamatan (Khan dkk, 2012). Penelitian membuktikan hasil pengamatan pada metode blok sel dapat secara akurat mendiagnosis kasus yang tidak terjawab pada metode pulasan cytospin (Mulkalwar, 2016). Dari total 60 kasus efusi pleura yang dicurigai keganasan, 56 diantaranya telah dikonfirmasi sebagai keganasan dan pada 46 kasus keganasan terdiagnosa oleh pembuatan bloksel (Ghosh dkk, 2012). Blok sel juga berguna dalam diagnosis yang lebih baik pada kasus neoplasma ganas yang kurang terdiferensiasi dalam imunositokimia. Kemampuan bloksel yang dapat memproduksi banyak potongan memungkinkan dilakukannya beberapa pewarnaan imunositokimia (Khan dkk, 2012).

Tahapan pembuatan bloksel diawali dari fiksasi untuk mempertahankan komponen sel serta keadaannya mendekati seperti aslinya. Fiksasi dapat mempengaruhi hasil blok sel, yaitu adanya waktu tunda fiksasi spesimen bloksel setelah pengumpulan spesimen dapat menyebabkan degenerasi pada sel. Pada tahap selanjutnya yaitu proses pematangan jaringan, lalu pembuatan blok parafin dengan merendamnya di dalam parafin (Prasetyani, 2017). Larutan fiksatif dalam pembuatan blok sel yaitu agar gel, Nathan Alcohol Formalin Substitute (NAFS), atau plasmatromboplastin. Larutan fiksatif NAFS terdiri dari 9 bagian etanol 100\% dan 1 bagian formalin 40\%. NAFS merupakan larutan fiksatif yang banyak digunakan untuk pembuatan bloksel karena lebih mudah didapatkan dibanding kedua larutan fiksatif lainnya.

Terdapat beberapa larutan fiksatif yang banyak tersedia di laboratorium patologi anatomi, salah satunya adalah alkohol 96\%. Alkohol 96\% merupakan salah satu larutan yang digunakan sebagai larutan fiksasi pada sitopatologi. Alkohol ini dipilih karena penetrasinya cepat dan dapat mengkoagulasi protein (Prasetyani, 2017). Alkohol 96\% memiliki daya dehidrasi yang kuat sehingga dapat mengeraskan jaringan. Ada juga larutan fiksatif lain yaitu NBF 10\% (Neutral Buffered Formalin). NBF 10\% merupakan 
larutan fiksatif yang sering digunakan untuk fiksasi jaringan serta banyak terdapat di laboratorium patologi anatomi.

Berdasarkan penelitian, pembuatan blok sel menggunakan NAFS maupun plasma-tromboplastin sudah terbukti dapat memberikan gambaran sel yang baik. Namun sampai saat ini penggunaan alkohol 96\%-NBF 10\% sebagai alternatif cairan fiksatif belum pernah dilakukan dan masih belum diketahui hasil kualitasnya yang berupa kualitas struktur sel maupun penyerapan warna. Oleh sebab itu, peneliti ingin mengetahui perbandingan hasil pembuatan blok sel antara yang menggunakan NAFS dengan yang menggunakan alkohol 96\%-NBF 10\%. Parameter penilaian yang akan dinilai terdiri dari gambaran morfologi sel, banyaknya sel yang dihasilkan, banyaknya sel ganas yang teranalisa, penyerapan pewarnaan serta sensitivitas sitodiagnosis.

\section{BAHAN DAN METODE}

Bahan yang digunakan pada penelitian ini adalah sampel cairan pleura, alkohol 96\%, NBF 10\% siap pakai, etanol 100\%, formalin 40\%, rak tabung, tabung sentrifus, pinset, alkohol 70\%, xylol, parafin, hot plate, waterbath, Excelsior AS, Histostar Embedding Module, base mould, Histostar Cold Module, kaset, sentrifus, pipet, label, pensil, mikrotom, kaca objek, asam alkohol, hematoxylin harris, eosin phloksin, EA 50, OG 6, lithium karbonat, $\mathrm{HCl} 0,4 \%$, kaca penutup, entelan, mikroskop.

Penelitian ini menggunakan eksperimental dengan desain penelitian cross-sectional dimana dilakukan penelitian pembuatan bloksel cairan pleura menggunakan larutan fiksatif NAFS dan alkohol 96\%-NBF $10 \%$. Penelitian ini terdiri dari lima tahap penelitian, yaitu:

\section{Pembuatan larutan fiksatif}

1) Larutan NAFS

Dimasukkan 9 bagian etanol kedalam tabung reaksi. Kemudian ditambahkan 1 bagian formalin $40 \%$. 
2) Larutan Alkohol 96\%-NBF 10\%

Disiapkan pula alkohol 96\% dan NBF 10\% siap pakai yang mengandung formalin 4\% dan phosphate buffer 0,05 M. Kemudian dimasukkan 9 bagian alkohol $96 \%$ kedalam tabung reaksi. Lalu ditambahkan 1 bagian NBF $10 \%$.

\section{Proses Fiksasi}

1) Fiksasi menggunakan NAFS

Dimasukkan cairan pleura ke dalam tabung sentrifus kemudian ditambahkan larutan NAFS 1:1 lalu didiamkan selama 1 jam.

2) Fiksasi menggunakan alkohol 96\%-NBF 10\%

Dimasukkan cairan pleura ke dalam tabung sentrifus kemudian ditambahkan campuran alkohol 96\%-NBF 10\% 1:1 kemudian didiamkan selama 1 jam. Disentrifus 2500 rpm selama 15 menit lalu supernatan dibuang. Ditambahkan campuran alkohol 96\%-NBF 10\% lalu didiamkan selama 1 hari.

\section{Pembuatan bloksel setelah terbentuk endapan hasil fiksasi}

Diambil endapan menggunakan pinset lalu di letakkan dikertas saring, dilipat lalu dimasukkan ke dalam kaset yang telah diberi identitas menggunakan pensil. Kaset dimasukkan ke rak kaset, kemudian rak kaset dimasukkan kedalam chamber pada alat Excelsior AS untuk pematangan jaringan. Alat tersebut secara otomatis akan melakukan proses fiksasi dengan merendam kaset kedalam formalin buffer 10\% selama 4 jam 30 menit, lalu proses dehidrasi dengan merendam kaset kedalam alkohol dengan konsentrasi bertingkat 70\%, 80\%, 96\% dan 100\% selama 6 jam, kemudian proses clearing dengan merendam kaset kedalam xylol selama 3 jam, serta proses infiltrasi parafin dengan merendam kaset kedalam parafin cair selama 4 jam. Setelah pematangan jaringan selesai, rak kaset diangkat dari chamber lalu kaset dikeluarkan dari rak kaset.

Kaset kemudian dimasukkan ke tissue storage tank pada alat Histostar Embedding Module untuk pembuatan blok parafin. Endapan yang telah melalui proses pematangan jaringan dikeluarkan dari kertas saring lalu 
dipindahkan menggunakan pinset ke base mould yang sesuai dengan ukurannya. Base mould yang berisi endapan kemudian diisi parafin cair menggunakan wax dispenser, letakkan tutup kaset diatas base mould. Lalu pindahkan base mould ke cold spot hingga parafin mengeras. Setelah parafin mengeras, pindahkan base mould ke coldplate pada alat Histostar Cold Module untuk mendinginkan blok. Setelah parafin membeku, lepaskan kaset dari base mould kemudian diletakkan diatas coldplate hingga siap dipotong.

\section{Pemotongan Blok Parafin}

Blok parafin dipotong menggunakan mikrotom setebal 3-5 mikron, kemudian hasil pemotongan diletakkan di waterbath dengan suhu $48^{\circ} \mathrm{C}$ hingga parafin mengembang. Kemudian diambil menggunakan kaca objek. Lalu letakkan kaca objek pada hotplate dengan suhu $70^{\circ} \mathrm{C}$ selama 15 menit.

\section{Pewarnaan Slide hasil Pemotongan}

Selanjutnya dilakukan Hematoxilin-Eosin pada sediaan dengan merendam sediaan ke dalam xylol I selama 5 menit, lalu dipindahkan ke xylol II selama 5 menit, kemudian sediaan dikeringanginkan hingga kering. Selanjutnya sediaan direndam dalam etanol selama 5 menit, dipindahkan ke dalam alkohol $96 \%$ selama 5 menit, lalu ke dalam alkohol 70\% selama 5 menit kemudian dibilas dengan air mengalir. Selanjutnya direndam dalam zat warna hematoxilin (HE Harris) selama 5-10 menit, lalu bilas dengan air mengalir selama 5-10 menit. Kemudian sediaan dicelupkan ke dalam larutan $\mathrm{HCl} 0,4 \%$ sebanyak 2 celup. Selanjutnya sediaan direndam dalam lithium carbonat selama 30 detik, lalu bilas dengan air mengalir. Kemudian rendam sediaan dalam alkohol 70\% lalu alkohol 96\% masing-masing selama 5 menit. Setelah itu, rendam sediaan dalam zat warna eosin phloksin selama 1-2 menit. Lalu celupkan sediaan ke dalam etanol I dan etanol II masing-masing 10 celup. Kemudian rendam sediaan dalam xylol I dan xylol II masing-masing selama 5 menit. Angkat dan tiriskan sediaan hingga kering. Kemudian teteskan entelan lalu ditutup dengan kaca penutup. 
Selanjutnya dilakukan pengamatan sediaan oleh dokter spesialis patologi anatomi (keterangan pembebasan persetujuan etik: NO. KEPKPKKJ3/107/III/2018)

\section{HASIL}

Penelitian terhadap 13 sampel cairan pleura yang dibuat sediaan bloksel di Laboratorium Patologi Anatomi RSUD Pasar Minggu dengan 2 macam perlakuan yakni menggunakan larutan fiksatif NAFS dan larutan fiksatif alkohol 96\%-NBF 10\%. Volume sampel cairan pleura bervariasi dari yang terkecil $6 \mathrm{~mL}$ dan yang terbanyak $1500 \mathrm{~mL}$. Berikut adalah hasil penilaian terhadap sediaan-sediaan tersebut.

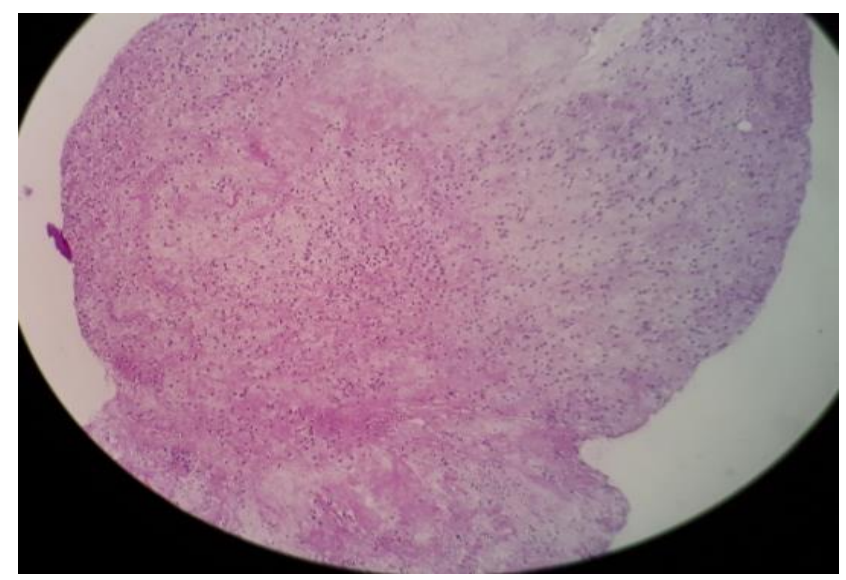

Gambar 1. Sediaan blok sel dengan larutan fiksatif NAFS (H\&E, 100x)

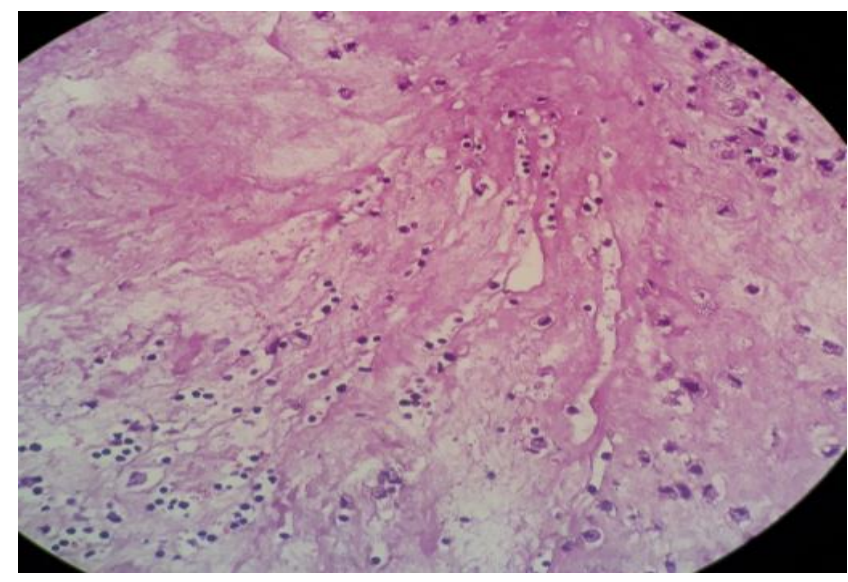

Gambar 2. Sediaan blok sel dengan larutan fiksatif NAFS (H\&E, 400x) 


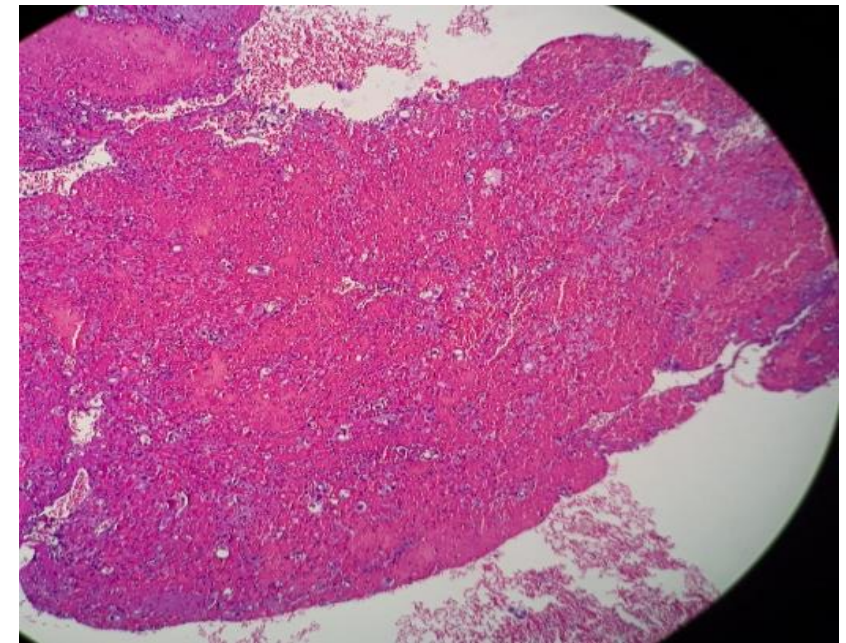

Gambar 3. Sediaan blok sel dengan larutan fiksatif alkohol $96 \%-N B F 10 \%$ (H\&E, 100x)

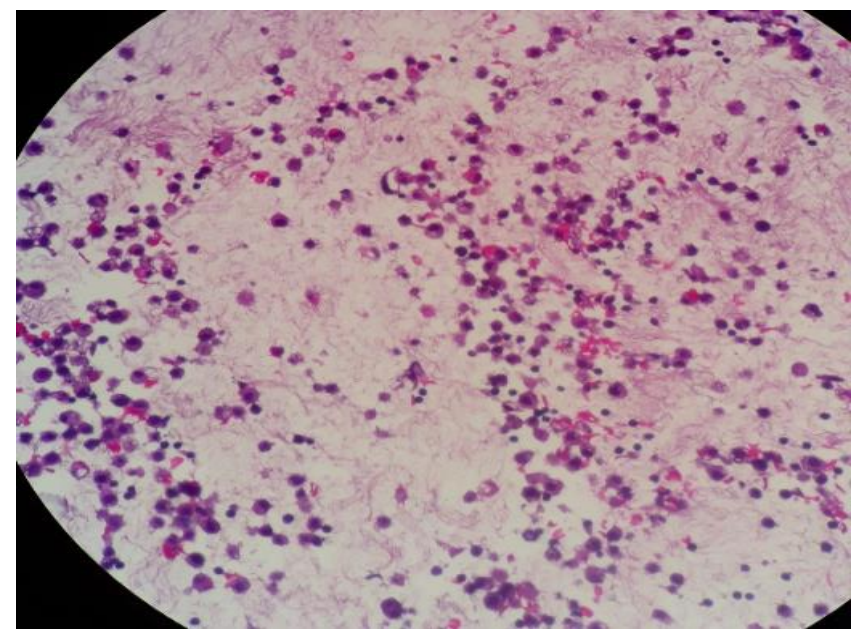

Gambar 4. Sediaan blok sel dengan larutan fiksatif alkohol 96\%-NBF 10\% (H\&E, 400x)

Pada gambar 1 dan 2 terlihat gambaran sediaan blok sel dengan larutan fiksatif NAFS, warna sediaan kemerahan dengan inti sel biru serta sel terkumpul pada satu bagian seperti yang terlihat pada perbesaran 100x dan 400x (Gambar 1 dan 2), semua sel dapat terlihat dengan baik. Pada Gambar 3 dan 4 terlihat gambaran sediaan bloksel dengan larutan fiksatif alkohol 96\%-NBF 10\%, warna yang dihasilkan kemerahan dengan inti sel biru. Distribusi sel pada sediaan tersebut terkumpul pada satu bagian seperti yang terlihat pada perbesaran 100x dan 400x (Gambar 3 
dan 4). Sel-sel pada sediaan ini terlihat dengan baik, kecuali eritrosit karena pada sediaan ini eritrosit lisis.

Hasil penilaian sediaan bloksel dengan larutan fiksatif NAFS terlihat pada tabel 1 menunjukkan gambaran morfologi selnya diperoleh satu sampel (7,7\%) termasuk kategori penilaian baik dan 12 sampel (92,3\%) termasuk kategori sangat baik. Berdasarkan banyaknya sel yang dihasilkan dan sensitivitas sitodiagnosisnya sebanyak masing-masing sembilan sampel $(69,2 \%)$ termasuk kategori baik dan empat sampel $(30,8 \%)$ termasuk kategori sangat baik.

Tabel 1. Hasil Penilaian Sediaan Bloksel dengan Larutan Fiksatif NAFS

\begin{tabular}{|c|c|c|c|c|c|c|c|c|c|c|c|c|}
\hline \multirow{3}{*}{$\begin{array}{l}\text { Parameter } \\
\text { Penilaian }\end{array}$} & \multicolumn{10}{|c|}{ Penilaian } & & \\
\hline & \multicolumn{2}{|c|}{$\begin{array}{l}\text { Sangat } \\
\text { Buruk }\end{array}$} & \multicolumn{2}{|c|}{ Buruk } & \multicolumn{2}{|c|}{ Cukup } & \multicolumn{2}{|c|}{ Baik } & \multicolumn{2}{|c|}{$\begin{array}{l}\text { Sangat } \\
\text { Baik }\end{array}$} & \multicolumn{2}{|c|}{ Jumlah } \\
\hline & (n) & $(\%)$ & (n) & (\%) & $\mathrm{n}$ & $\%$ & $\mathrm{n}$ & $\%$ & $\mathrm{n}$ & $\%$ & $\mathrm{n}$ & $\%$ \\
\hline $\begin{array}{c}\text { Gambaran } \\
\text { morfologi sel }\end{array}$ & 0 & 0 & 0 & 0 & 0 & 0 & 1 & 7,7 & 12 & 92,3 & 13 & 100 \\
\hline $\begin{array}{c}\text { Banyaknya sel } \\
\text { yang dihasilkan }\end{array}$ & 0 & 0 & 0 & 0 & 0 & 0 & 9 & 69,2 & 4 & 30,8 & 13 & 100 \\
\hline $\begin{array}{c}\text { Banyaknya sel } \\
\text { ganas yang } \\
\text { teranalisa }\end{array}$ & 0 & 0 & 0 & 0 & 1 & 50 & 1 & 50 & 0 & 0 & 2 & 100 \\
\hline $\begin{array}{l}\text { Penyerapan } \\
\text { pewarnaan }\end{array}$ & 0 & 0 & 0 & 0 & 0 & 0 & 4 & 30,8 & 9 & 69,2 & 13 & 100 \\
\hline $\begin{array}{l}\text { Sensitivitas } \\
\text { sitodiagnosis }\end{array}$ & 0 & 0 & 0 & 0 & 0 & 0 & 9 & 69,2 & 4 & 30,8 & 13 & 100 \\
\hline Jumlah & 0 & 0 & 0 & 0 & 1 & 5,4 & 24 & 44,4 & 29 & 53,7 & 54 & 100 \\
\hline
\end{tabular}

Tabel 2 memperlihatkan hasil penilaian terhadap sediaan bloksel dengan larutan fiksatif alkohol 96\%-NBF 10\%. Berdasarkan gambaran morfologi selnya sebanyak satu sampel (7,7\%) termasuk kategori penilaian buruk, tiga sampel $(23,1 \%)$ termasuk kategori baik dan sembilan sampel $(69,2 \%)$ termasuk kategori sangat baik. Berdasarkan banyaknya sel yang dihasilkan sebanyak empat sampel dengan kategori buruk, satu sampel (7,7\%) termasuk kategori cukup, dan delapam sampel $(61,5 \%)$ termasuk kategori sangat baik. Berdasarkan banyaknya sel ganas yang teranalisa dari dua sampel (100\%) sebanyak masing-masing satu sampel (50\%) termasuk kategori buruk dan cukup. Berdasarkan 
penyerapan pewarnaan dan sensitivitas sitodiagnosis sebanyak masingmasing satu sampel (7,7\%) termasuk kategori buruk, tiga sampel termasuk kategori cukup, satu sampel $(7,7 \%)$ termasuk kategori baik dan delapan sampel $(61,5 \%)$ kategori sangat baik.

Tabel 2. Hasil Penilaian Sediaan dengan Larutan Fiksatif Alkohol 96\%-NBF 10\%

\begin{tabular}{|c|c|c|c|c|c|c|c|c|c|c|c|c|}
\hline \multirow{3}{*}{$\begin{array}{c}\text { Parameter } \\
\text { Penilaian }\end{array}$} & \multicolumn{10}{|c|}{ Penilaian } & & \\
\hline & \multicolumn{2}{|c|}{$\begin{array}{l}\text { Sangat } \\
\text { Buruk }\end{array}$} & \multicolumn{2}{|c|}{ Buruk } & \multicolumn{2}{|c|}{ Cukup } & \multicolumn{2}{|c|}{ Baik } & \multicolumn{2}{|c|}{$\begin{array}{l}\text { Sangat } \\
\text { Baik }\end{array}$} & \multicolumn{2}{|c|}{ Jumlah } \\
\hline & $\mathrm{N}$ & $\%$ & $\mathrm{n}$ & $\%$ & $\mathrm{n}$ & $\%$ & $\mathrm{n}$ & $\%$ & $\mathrm{n}$ & $\%$ & $n$ & $\%$ \\
\hline $\begin{array}{l}\text { Gambaran } \\
\text { morfologi sel }\end{array}$ & 0 & 0 & 1 & 7,7 & 0 & 0 & 3 & 23,1 & 9 & 69,2 & 13 & 100 \\
\hline $\begin{array}{c}\text { Banyaknya sel yang } \\
\text { dihasilkan }\end{array}$ & 0 & 0 & 4 & 30,8 & 1 & 7,7 & 0 & 0 & 8 & 61,5 & 13 & 100 \\
\hline $\begin{array}{c}\text { Banyaknya sel } \\
\text { ganas yang } \\
\text { teranalisa }\end{array}$ & 0 & 0 & 1 & 50 & 1 & 50 & 0 & 0 & 0 & 0 & 2 & 100 \\
\hline $\begin{array}{l}\text { Penyerapan } \\
\text { pewarnaan }\end{array}$ & 0 & 0 & 1 & 7,7 & 3 & 23,1 & 1 & 7,7 & 8 & 61,5 & 13 & 100 \\
\hline $\begin{array}{l}\text { Sensitivitas } \\
\text { sitodiagnosis }\end{array}$ & 0 & 0 & 1 & 7,7 & 3 & 23,1 & 1 & 7,7 & 8 & 61,5 & 13 & 100 \\
\hline Jumlah & 0 & 0 & 8 & 14,8 & 8 & 14,8 & 5 & 9,3 & 33 & 61,1 & 54 & 100 \\
\hline
\end{tabular}

Uji statistik dalam penelitian ini menggunakan uji Friedman antara sediaan bloksel dengan larutan fiksatif NAFS dan sediaan bloksel dengan larutan fiksatif alkohol 96\%-NBF 10\%. Pada table 3 dapat dilihat bahwa hasil uji friedman pada semua parameter penilaian menunjukkan nilai $\mathrm{p}$ lebih besar dari 0,05 maka $\mathrm{HO}$ diterima, artinya tidak terdapat perbedaan yang bermakna antara sediaan bloksel dengan larutan fiksatif NAFS dan sediaan bloksel dengan larutan fiksatif alkohol 96\%-NBF 10\%.

Tabel 3. Uji Friedman Hasil Penilaian Sediaan Cairan Pleura

\begin{tabular}{ccc}
\hline Parameter Penilaian & Nilai $\mathbf{p}$ & Simpulan $(\mathbf{a}=\mathbf{0 , 0 5 )}$ \\
\hline $\begin{array}{c}\text { Gambaran morfologi sel } \\
\begin{array}{c}\text { Banyaknya sel yang } \\
\text { dihasilkan }\end{array}\end{array}$ & 0,074 & Tidak beda bermakna \\
\hline $\begin{array}{c}\text { Banyaknya sel ganas yang } \\
\text { teranalisa }\end{array}$ & 0,584 & Tidak beda bermakna \\
\hline Penyerapan pewarnaan & 0,223 & Tidak beda bermakna \\
\hline Sensitivitas sitodiagnosis & 0,223 & Tidak beda bermakna \\
\hline
\end{tabular}




\section{DISKUSI}

Analisa sitologi cairan pleura di laboratorium patologi anatomi memegang peran penting dalam menegakkan diagnosis awal keganasan. Metode analisa sitologi cairan pleura yang paling sering dilakukan adalah dengan membuat sediaan pulasan konvensional langsung pada saat sampel datang. Metode ini dapat dilakukan dengan cepat dan dalam 1 sampai 3 hari hasil diagnosis sudah bisa diperoleh. Terdapat pula metode lain untuk analisa sitologi cairan pleura yaitu bloksel. Metode ini memerlukan paling sedikit 3 hari pengerjaan untuk memperoleh hasil diagnosis. Lebih lama jika dibandingkan dengan pulasan konvensional. Namun metode ini memiliki keunggulan yaitu sediaannya dapat di produksi ulang serta dapat disimpan untuk keperluan pemeriksaan lanjutan yang tidak dapat dilakukan pada pulasan konvensional (Prasetyani, 2017).

Gambaran pulasan sediaan bloksel dengan larutan fiksatif NAFS (Gambar 1 dan 2) dan sediaan bloksel dengan larutan fiksatif alkohol 96\%NBF 10\% (Gambar 3 dan 4) berwarna kemerahan dengan inti sel biru karena menggunakan pewarnaan H\&E. Pada pulasan bloksel distribusi sel terpusat pada satu tempat, karena sel berkumpul dalam sebuah padatan (Prasetyani, 2017).

Perbandingan hasil antara sediaan bloksel dengan larutan fiksatif NAFS dan alkohol 96\%-NBF 10\% terlihat jelas pada jumlah kategori penilaian buruk yaitu, terdapat 8 kali $(14,8 \%$ ) pada sediaan dengan alkohol 96\%-NBF 10\% sedangkan pada sediaan dengan NAFS tidak terdapat penilaian buruk. Penilaian buruk pada sediaan dengan alkohol 96\%-NBF 10\% paling banyak disumbangkan dari parameter penilaian banyaknya sel yang dihasilkan yaitu sebanyak 4 kali $(7,4 \%)$. Hal ini mungkin disebabkan konsentrasi formalin yang digunakan lebih tinggi pada NAFS yaitu 10\% formalin, sedangkan pada alkohol 96\%-NBF 10\% hanya mengandung sekitar 1\% formalin. Sehingga mempengaruhi jumlah sel yang terpenetrasi formalin. Akibatnya sel yang tidak terpenetrasi ikut terbuang bersama supernatan. 
Hal lain yang terlihat jelas antara sediaan bloksel dengan larutan fiksatif NAFS dan alkohol 96\%-NBF 10\% yaitu pada sediaan bloksel dengan larutan fiksatif alkohol 96\%-NBF 10\% terdapat 33 penilaian sangat baik $(61,1 \%)$, lebih banyak jika dibandingkan dengan sediaan bloksel dengan larutan fiksatif NAFS yang hanya sebanyak 29 penilaian (53,7\%) (Santoshpawar dkk, 2016).

Pada penelitian ini terdapat sedikit kendala yaitu, peneliti melakukan analisis pada 16 sampel cairan pleura tetapi hanya 13 data hasil penelitian yang digunakan. Hal ini dikarenakan pada satu sampel dengan larutan fiksatif NAFS dan larutan fiksatif alkohol 96\% -NBF 10\% tidak terbentuk bloksel dan pada dua sampel dengan larutan fiksatif alkohol 96\%-NBF 10\% tidak terbentuk bloksel. Data hasil yang tidak lengkap pada sampel akan mengganggu saat dilakukan uji statistik sehingga data tersebut tidak diperhitungkan. Bloksel yang tidak terbentuk pada satu sampel dengan larutan fiksatif NAFS dan larutan fiksatif alkohol 96\%-NBF 10\% mungkin disebabkan karena jumlah sampel yang terlalu sedikit disertai dengan jumlah sel yang sedikit pula. Karakteristik sampel yang tidak terbentuk bloksel tersebut yaitu berwarna kuning jernih dengan volume sampel yang dibuat bloksel masing-masing 2,5 mL. Penyebab adanya dua sampel dengan larutan fiksatif alkohol 96\%-NBF 10\% yang tidak terbentuk bloksel selain karena faktor volume sampel dan jumlah sel, keberadaan sel darah merah juga dapat mempengaruhi keberhasilan pembuatan bloksel. Hal ini dapat dilihat dari karakteristik sampel berwarna kuning kemerahan. Keadaan ini sesuai dengan pernyataan Shamsi, M dkk (2008) bahwa alkohol 96\% dapat menghemolisis eritrosit. Hal tersebut juga sejalan dengan hasil sediaan bloksel dengan larutan fiksatif alkohol 96\%-NBF 10\% menggambarkan sel eritrosit yang tidak dapat terlihat dengan baik karena lisis. 
Berdasarkan uji statistik (tabel 1) menunjukkan tidak terdapat perbedaan yang bermakna pada sediaan tersebut terhadap semua parameter penilaian (100\%). Artinya tidak terdapat perbedaan hasil sediaan pula antara bloksel dengan larutan fiksatif NAFS dan alkohol 96\%-NBF 10\%. Hal ini disebabkan karena secara teknis kedua campuran larutan fiksatif tersebut berasal dari bahan dasar yang sama yaitu alkohol dan formalin. Berdasarkan hasil tersebut dapat disimpulkan larutan fiksatif alkohol 96\%NBF $10 \%$ dapat digunakan sebagai larutan fiksasi dalam pembuatan bloksel pada cairan pleura.

\section{KESIMPULAN}

Berdasarkan penilaian sediaan cairan pleura dalam bentuk pulasan sediaan bloksel dengan larutan fiksatif NAFS serta sediaan bloksel dengan larutan fiksatif alkohol 96\%-NBF 10\% dapat disimpulkan tidak ada perbedaan bermakna pada gambaran morfologi sel, banyaknya sel yang dihasilkan, banyaknya sel ganas yang teranalisa, penyerapan pewarnaan dan sensitivitas sitodiagnosis dari sediaan tersebut. Sehingga larutan fiksatif alkohol 96\%NBF $10 \%$ dapat digunakan sebagai larutan alternatif.

\section{KONFLIK KEPENTINGAN}

Peneliti mengucapkan terimakasih kepada Kapala Laboratorium Patologi Anatomi Rumah Sakit Umum Daerah Pasar Minggu dan Jurusan Teknologi Laboratorium Medis, Poltekkes Kemenkes Jakarta III.

\section{KONFLIK KEPENTINGAN}

Seluruh penulis tidak memiliki konflik kepentingan dalam penelitian ini. 


\section{REFERENSI}

Boka, K., et al. 2017. Pleural Effusion Guidelines. Medscape: Drug and Diseases-Pulmonology. Dilihat $15 \quad$ Januari 2018 https://emedicine.medscape.com/article/299959-guidelines\#g2.

Centrifugation Cell Preparation System. Automation. Dilihat 16 Januari 2018 http: //www.scientistlive.com/content/9269.

Chowdhuri, S. R., et al. 2015. Optimizing the DNA yield for Molecular Analysis from Cytologic Preparations. Journal Cancer Cytopathology. Vol. 124. Issue 4. Dilihat 15 Januari 2018 http://onlinelibrary.wiley.com/doi/10.1002/cncy.21664/full?wol1UR $\mathrm{L}=/ \mathrm{doi} / 10.1002 /$ cncy.21664/full\&regionCode=ID\&identityKey=96fcd9 03-550a-4e5c-b910-38751ef4adea.

Chowdhuri, S. R., Stewart, J. 2016. Lessons Learned From Next-Generation Sequencing-The MD Anderson Experience. Journal Archives of Pathology Laboratory Medical. Dilihat 14 Januari 2018 http: //www.archivesofpathology.org/doi/pdf/10.5858/arpa.20160117-RA?code=coap-site.

Dokter Indonesia. 2017. Angka Kejadian Kanker Paru Di Dunia Dan Indonesia. Dilihat 23 November 2017 <https: / /dokterindonesiaonline.com/2017/04/27/angka-kejadiankanker-paru-di-dunia-dan-indonesia/>.

Ettinger, D. S. 2011. Lung Cancer and Other Pulmonary Neoplasm. Goldman's Cecil Medicine. Edn 24th. Vol. 1. Elsevier Inc.

Ghosh I 2012. Cell block cytology in pleural effusion. PubMed. Dilihat 20 November 2017. <https://www.ncbi.nlm.nih.gov/pubmed/23360042>

Hezer S, et al 2015. Ekspresi Kalretinin Pada Diagnosis Sitologi Efusi Pleura dengan Gambaran Sitomorfologi Adenokarsinoma. . Biomedika. Vol 7 No 1. Semarang

Hu, X., et al. 2015. A Simple and Efficient Method for Preparing Cell Slides and Staining without Using Cytocentrifuge and Cytoclips. International Journal of Cell Biology. Volume 2015. USA

Kementerian Kesehatan RI. 2015. Pusat Data dan Informasi. Kementerian Kesehatan RI. Jakarta.

Khairani, R., et al. 2012. Karakteristik Efusi Pleura di Rumah Sakit Persahabatan. Jurnal Respir Indo. Vol.32. No 3. Jakarta.

Khan, S., et al. 2012. Effectiveness of The Cell Block Technique in iagnostic Cytopathology. Journal of Cytology. Vol. 29. Dilihat 13 Januari 2018 https://www.ncbi.nlm.nih.gov/pmc/articles/PMC3480766/. 
Khristian, E., Inderiati, D. 2017. Sitohistoteknologi. Bahan Ajar Teknologi Laboratorium Medik (TLM). Badan Pengembangan Dan Pemberdayaan Sumber Daya Manusia Kesehatan. Jakarta.

Kristina, F. 2014. Hubungan Profil Sitologi Cairan Pleura dengan Profil Pasien Kanker Paru di RS Immanuel Bandung Periode Juli 2010 - Juni 2013. Undergraduate thesis. Universitas Kristen Maranatha. Bandung.

Mulkalwar, M et al 2016. Diagnostic Utility of Cell Block Method versus Cytospin Method in Pleural and Peritoneal Fluid Cytology. Journal of Medical Science and and clinical research. India.

Nainggolan, S Y. 2017. Persentase Kanker Paru Terus Meningkat Tiap Tahun. Dilihat $24 \quad$ November 2017 http://rona.metrotvnews.com/read/2017/06/16/716685/persentasekanker-paru-terus-meningkat-tiap-tahun.

Nathan, N A, et al. 2015. Cell Block Cytology: Improved Preparation snd Its Efficacy in Diagnostic Cytology. American Journal of Clinical Pathology. Vol 114.

Prakriti Shukla, Sukhpreet Kaur and Hanni V Gulwani. 2015. Diagnostic utility of Plasma Thromboplastin cell block preparation in cytological evaluation of serous effusions. International Journal of Biomedical Research. India

Prasetyani, T. 2017. Gambaran Mikroskopis Histologi Bloksel Efusi Pleura dengan Menggunakan Fiksasi Alkohol 70\% dan BNF 10\% pada Pewarnaan HE. Diploma thesis. Universitas Muhammadiyah Semarang.

Rahman, A., et al. 2011. Role of Pleural Biopsy in the Etiological Diagnosis of Exudative Pleural Effusion. Journal ANNALS. Vol. 17. No. 1. Lahore, Pakistan.

Santoshpawar, et al 2016. Sensitivity and Specificity of Cell Block Method in Diagnosis of Lung Malignancies. Journal of Dental and Medical Sciences. Volume 15, Issue 4

Satolom, M., et al. 2012. Karakteristik Vascular Endothelial Growth Factor, Glukosa, Lactate Dehydrogenase dan Protein pada Efusi Pleura Non Maligna dan Efusi Pleura Maligna. Jurnal Respir Indo. Vol. 32. No. 3.

Shamsi, M., Abdali, K., Montazer, N.R., Kumar, P.V., and Tabatabaee, H.R. 2008. Comparison of carnoy's solution and $96 \%$ ethyl alcohol fixation in bloody pap smears. Acta Cytologica. Vol. 52. No. 2. Shiraz University of Medical Sciences. Iran.

Shivakumarswamy, U., et al 2012. Diagnostic utility of the cell block method versus the conventional smear study in pleural fluid cytology. Journal of Cytology. Dilihat $20 \quad$ November 2017. https://www.ncbi.nlm.nih.gov/pmc/articles/PMC3307444/\#

Shobha SN and Kodandaswamy CR 2013. Utility of Modified Cell Block Technique in Cases of Pleural Effusion Suspected of Malignancy. Dilihat 20 November 2017 <http: / /www.scopemed.org/?mno=165769> 
Syahruddin, E., et al. 2010. A Retrospective Study: Clinical and Diagnostic Characteristics in Advanced Stage of Lung Cancer Patients with Pleural Effusion in Persahabatan Hospital 2004 - 2007. Jurnal Respir Indo. Vol. 30. No. 3.

Varsegi, G. M., Shidham, V. 2009. Cell Block Preparation from Cytology Specimen with Predominance of Individually Scatterd Cells. Journal of Visualized Experiments.

Wande, I. N. 2016. Buku panduan interpretasi analisis cairan pleura. Bagian Patologi Klinik Fakultas Kedokteran Universitas Udayana, Bali. 